\title{
Is the forum of disaster risk reduction ready?: Disaster preparedness in a community setting
}

\author{
Happy Indah Kusumawati, Sutono, ${ }^{*}$ Sri Setiyarini, Bayu Fandhi Achmad, Angela Dwi Hesti \\ Ariningtyas, Istighfarlin Widyanita, Syahirul Alim
}

Department of Basic and Emergency Nursing, Faculty of Medicine, Public Health, and Nursing, Universitas Gadjah Mada, Yogyakarta, Indonesia

\author{
SUBMITTED: 26 April 2021 REVISED: 20 May 2021 ACCEPTED: 20 June 2021
}

KEYWORDS

Disaster

preparedness

Community level

Forum of disaster risk reduction

\begin{abstract}
A community-based forum, Forum Pengurangan Resiko Bencana (FPRB), or Forum of Disaster Risk Reduction was established to accommodate and collaborate with stakeholders to optimize disaster management according to local capacity. However, evaluation of disaster preparedness among FPRB members is rarely done. Therefore, this study aimed to determine the disaster preparedness and level of Basic Life Support (BLS) knowledge among FPRB members in Bantul. A descriptive study was conducted with a cross-sectional design. Participants $(n=77)$ were members of FPRB in Poncosari sub-district, Srandakan district, and Girirejo sub-district, Imogiri district, Bantul Regency. The survey was undertaken using the modified Disaster Preparedness Indonesian Institute of Science (LIPI)-UNESCO 2006 questionnaire and modified BLS American Heart Association (AHA) 2015 questionnaire. Univariate analysis was utilized to analyze data. Overall, the majority (52\%) of disaster preparedness levels among FPRB members was categorized as strong level (median $=29$ ). Related to the disaster preparedness aspect, $89 \%$ had good disaster knowledge, followed by resource mobilization $(75 \%)$, urgent plan $(60 \%)$, and early warning (53\%). The median score of BLS knowledge was 5.38 (min-max = 2-9). Most of the participants (56\%) had a good level of BLS knowledge. This study highlights that the disaster knowledge aspect is indicated as a highly familiar aspect while the early warning aspect is identified as a low familiar one. This study assists policymakers to develop a strategic plan to promulgate further disaster and first aid training in the community setting.
\end{abstract}

(c) The Journal 2021. This article is distributed under a Creative Commons Attribution-ShareAlike 4.0 International license.

\section{Introduction}

Indonesia is one of the most disaster-affected nations on the earth. Being located in an area with a high degree of tectonic activity (Pacific plate), Indonesia has to cope with a constant risk of earthquakes. The Pacific plate is the most active one which contributes to $90 \%$ of the earthquakes in the world. ${ }^{1}$ Between 2017 - 2018, Indonesia experienced 106 earthquakes and two tsunamis, accounting for 583 deaths. ${ }^{2}$

Current disaster management efforts are focused on disaster risk reduction (DRR). According to the Sendai Framework for DRR, there are four priorities for efforts to reduce disaster risk, and one of the priorities is to improve disaster preparedness for an

*Correspondence: sutono_ugm@ugm.ac.id

Department of Basic and Emergency Nursing, Faculty of Medicine, Public Health and Nursing, Universitas Gadjah Mada, J. Farmako, Sekip Utara, Yogyakarta 55281, Indonesia effective response. ${ }^{3}$ This framework also emphasizes the importance of building a resilient community to face disasters and forms a new paradigm in which DRR is an integrated task and collaboration among government, private sector, and community. ${ }^{3}$

The Indonesian government has built efforts to enhance disaster management capacity. The Indonesian Law No. 24/2007 about Disaster Management and Government Rule No. 21/2008 stated the need to establish a community-based forum to facilitate and reduce disaster risk namely the Forum Pengurangan Resiko Bencana (FPRB). The involvement of various elements (i.e. community leaders as role models) in the preparedness phase is important to optimize DRR.

The Special Region of Yogyakarta (DIY), especially the Bantul Regency, experienced an earthquake (magnitude 6.3 Richter Scale) which caused 
thousands of casualties and severe infrastructure damage in 2006. ${ }^{4}$ It occurred because DIY is located on the Australian and Eurasian tectonic plates. Apart from geographical factors, high population density and settlement are factors that increase earthquake vulnerability. Bantul Regency, with an area of 506.85 $\mathrm{km}^{2}$, with a population of 955,952 and a population density of 1,884 people/ $/ \mathrm{km}^{2}$, is categorized as a densely populated area which is prone to earthquakes. ${ }^{5}$ FPRB, which is located in Bantul, is a social organization developed independently by the community or initiated by the government. This forum consists of some elements of society such as village leaders, youth organizations, cadres, community members, etc. who come from their subdistricts. FPRB members conduct monthly meetings to discuss several programs/issues such as contingency plans and evacuation routes, to promote disaster education for the community, to create simulation/training in collaboration with Regional Disaster Mitigation Agency (BPBD) or Indonesian Red Cross, etc.

This forum is still facing problems in terms of sustainability and consistency to implement its programs or activities. Moreover, evaluation of disaster preparedness, including disaster knowledge, resource mobilization, urgent plan, early warning, and BLS among FPRB members is rarely done. Accordingly, this study aimed to investigate the disaster preparedness among FPRB in Poncosari and Girirejo sub-districts, Bantul to tackle the disaster.

\section{Method}

This study was a descriptive study with a crosssectional design using a survey conducted in two regions, in Poncosari and Girirejo in March 2020. Those sub-districts are the first places that initiated the establishment of FPRB in Bantul. Moreover, Poncosari is located near the Samas beach and Girirejo is located near the Opak plate which is vulnerable to disaster.

The participants involved in this study were 77 FPRB members located in Poncosari sub-district (Srandakan, Bantul) and Girirejo sub-district (Imogiri, Bantul). Purposive sampling was used in this study.
All participants met the inclusion criteria: aged 18 years or over and either had or no previous disaster training.

Data were collected by using a modified questionnaire developed by the Indonesia Institute of Science-UNESCO (LIPI-UNESCO) 2006 for disaster preparedness and by the American Heart Association (AHA) 2015 for Basic Life Support (BLS). Some items of the instrument were modified to fit the context and role of FPRB. ${ }^{6}$ The total of 34 questions of disaster preparedness and 10 questions of BLS knowledge were used. The Guttman scale was used for both questionnaires. For the disaster preparedness questionnaire, the interval used was the choice of answers between "yes" and "no" with a score of 1 for "yes" answer and a score of 0 for "no" answers. For BLS knowledge, a multiple-choice option was used.

Univariate analysis was conducted to summarize demographic data such as age, gender, family role, education level, occupation, income, previous disaster training and experience, and involvement as FPRB member (years). Disaster preparedness which consists of some aspects including disaster knowledge ( 3 items), resource mobilization (8 items) urgent plan (13 items), early warning (10 items), and BLS knowledge (10 items) are also presented and analyzed using tables and figures. The study was approved by the Medical and Health Research Ethics Committee at the Faculty of Medicine, Public Health and Nursing, Universitas Gadjah Mada Indonesia (registration number Ref: KE/FK/0027/EC/2020).

\section{Result}

\subsection{Baseline of characteristics}

A total of 77 participants were involved in this study. The majority of respondents were aged $41-$ 60 years (53\%). More than three-quarters of them were males (83\%) and had a role as a father. Most of the participants were graduated from high school (71\%) and employed (88\%). The monthly income of participants was $\geq \operatorname{Rp~} 1.649 .800,00$. The majority of participants had experienced a disaster and had prior experience disaster training. The average years of involvement as an FPRB member were 4.74. 
Table 1. Demographic data of FPRB members in Poncosari and Girirejo sub-districts, March $2020(n=74)$

\begin{tabular}{|c|c|c|c|}
\hline Demographic Data & Number & $\%$ & $\begin{array}{l}\text { Mean } \pm \\
\text { SD }\end{array}$ \\
\hline \multicolumn{4}{|l|}{ Age } \\
\hline $20-40$ & 32 & 42 & \\
\hline $41-60$ & 41 & 53 & \\
\hline$>60$ & 4 & 5 & \\
\hline \multicolumn{4}{|l|}{ Gender } \\
\hline Male & 64 & 83 & \\
\hline Female & 13 & 17 & \\
\hline \multicolumn{4}{|l|}{ Family Role } \\
\hline Father & 53 & 69 & \\
\hline Mother & 12 & 16 & \\
\hline Child & 12 & 16 & \\
\hline \multicolumn{4}{|l|}{ Level of Education } \\
\hline Junior high & 4 & 5 & \\
\hline High school & 55 & 71 & \\
\hline Diploma/University & 18 & 24 & \\
\hline \multicolumn{4}{|l|}{ Occupation } \\
\hline Not Occupied & 9 & 12 & \\
\hline Occupied & 68 & 88 & \\
\hline \multicolumn{4}{|l|}{ Income (monthly) } \\
\hline$<\operatorname{Rp} 1.649 .800,-$ & 34 & 44 & \\
\hline$\geq \operatorname{Rp} 1.649 .800,-$ & 43 & 56 & \\
\hline \multicolumn{4}{|l|}{ Previous disaster experience } \\
\hline Yes & 67 & 87 & \\
\hline \multicolumn{4}{|l|}{ Previous disaster training } \\
\hline Yes & 69 & 90 & \\
\hline $\begin{array}{l}\text { Years involved as FPRB } \\
\text { member }\end{array}$ & & & $\begin{array}{l}4.74 \pm \\
3.49\end{array}$ \\
\hline
\end{tabular}

\subsection{Level of preparedness}

Most of the participants had a total score of preparedness $31(18 \%)$, with one respondent each who had the highest and lowest score (Figure 1). The median score of preparedness was 29 . To identify the preparedness level among FPRB members, the overall preparedness was classified into two categories (weak $=<29$ and strong $=\geq 29$ ). Overall, most of the participants had a strong disaster preparedness (52\%).

\subsection{Level of preparedness based on preparedness aspect}

Table 2 shows the median score of each aspect consisting of disaster knowledge, resource mobilization, urgent plan, and early warning. An aspect of preparedness was categorized into two levels: a strong level if aspect score was $\geq$ median and a weak level if aspect score was $<$ median. As shown in Figure 2, all of the aspects investigated in this study showed that participants had a strong level of preparedness. Related to the disaster preparedness aspect, $89 \%$ had good disaster knowledge, followed by resource mobilization (75\%), urgent plan (60\%), and early warning (53\%) (Fig. 2). Among those aspects, participants were identified as highly familiar with the disaster knowledge aspect. However, they had a low-level familiarity with the early warning aspect.

\subsection{The aspect of disaster preparedness}

Related to the disaster knowledge aspect, most participants chose the correct answer about characteristics of disaster (95\%) while they mostly chose the wrong ones about the cause of the earthquake (44\%). In the resource mobilization aspect, the majority of the FPRB team agrees with the statement of involvement of the BPBD or other agency to undertake disaster training (97\%). However, they stated that they did not participate in meetings routinely held by FPRB $(87 \%)$. In the urgent plan aspect, most of the participants obtained information about the earthquake from social media (97\%). Conversely, the majority of the FPRB team had no effort to increase knowledge about the earthquake as preparation (66\%). In the early warning aspect, most participants disagreed that they obtained information about aftershocks from television (61\%).

\subsection{Overall score of BLS knowledge}

A total of 77 participants were involved in this study. The median score of BLS knowledge was 5. BLS score was categorized into the two levels: good level if aspect score was $\geq$ median and poor level if aspect score was < median. The majority of respondents had a good level of BLS knowledge (56\%). Most of the participants had high-level familiarity with the recovery position item and low-level familiarity with the item how to check patient response.

\section{Discussion}

This is the first study to explore both disaster preparedness and BLS among FPRB members in Bantul, DIY. The results highlight a wide range of issues including disaster knowledge, early warning, and BLS. 


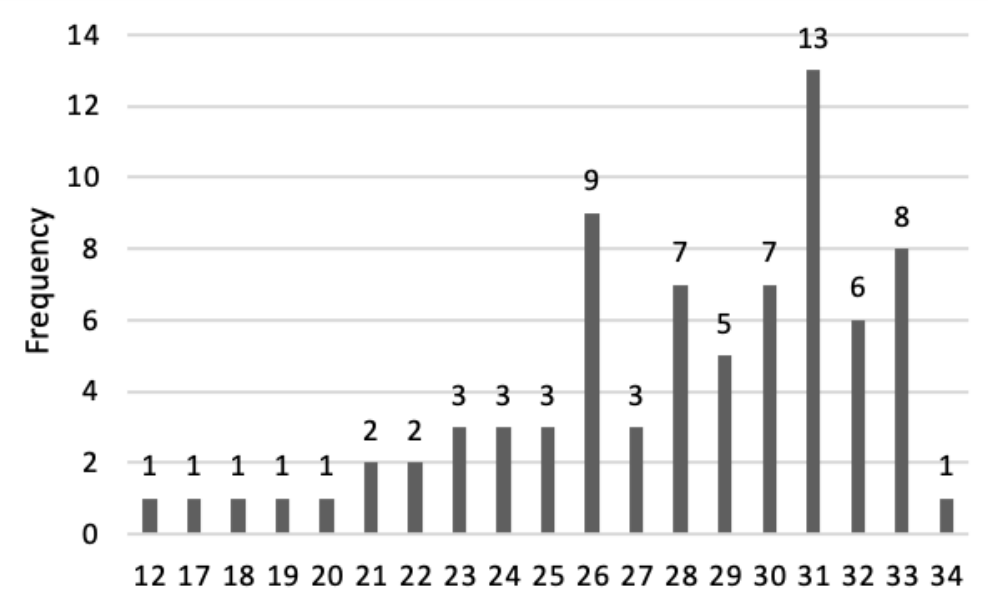

Figure 1. Total score of disaster preparedness among FPRB members.

Table 2. Median score based on disaster preparedness aspect

\begin{tabular}{lllll}
\hline Aspect & Number of items & Median & Min & Max \\
\hline Knowledge & 3 & 2.00 & 1.00 & 3.00 \\
Resource mobilization & 8 & 7.00 & 4.00 & 8.00 \\
Urgent plan & 13 & 11.00 & 6.00 & 13.00 \\
Early warning & 10 & 9.00 & 3.00 & 10.00 \\
\hline
\end{tabular}

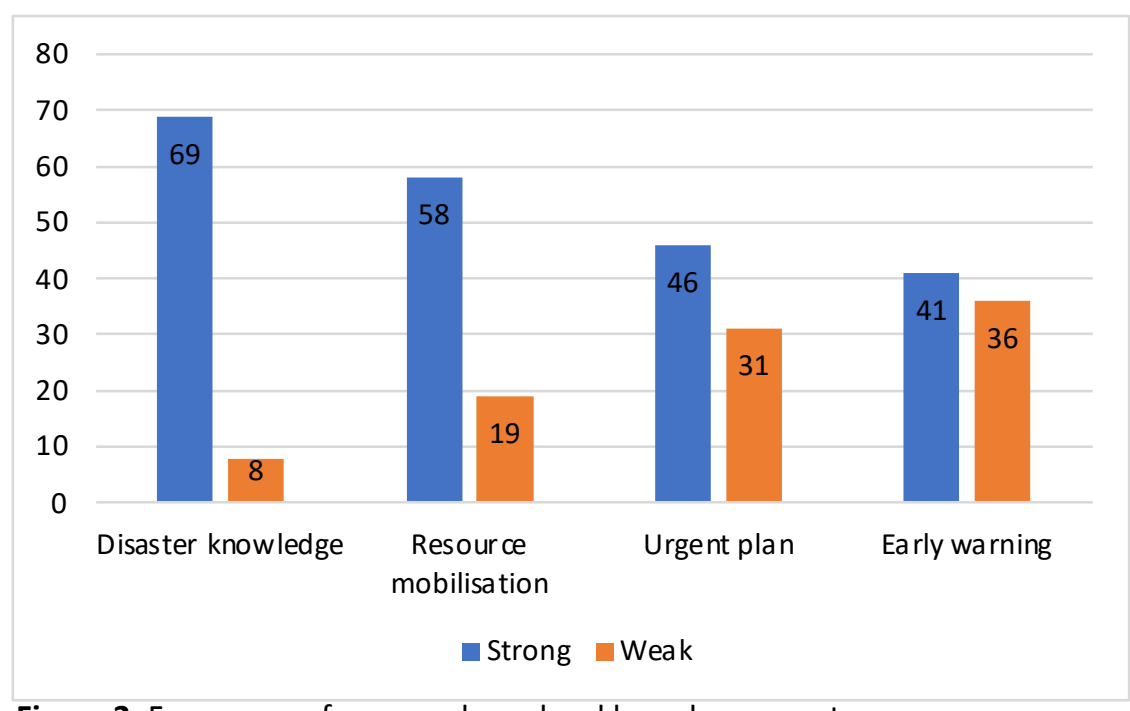

Figure 2. Frequency of preparedness level based on aspect

Our study showed that the majority of FPRB members have a strong level of preparedness to tackle disaster events, previous disaster experience, and disaster training experience. This result is congruent with studies in Aceh, Indonesia, and China that found that people who live in disaster-affected locations and the rural area had a high level of preparedness. ${ }^{7,8}$ In this study, most of the participants had prior experience to respond to disaster and lived in areas that were nearby the rivers and the sea which are highly prone to suffer disaster. It can be assumed that they have a better understanding and preparedness to cope with disaster through the experience. More than a decade ago, DIY (Bantul regency) experienced huge earthquakes (magnitude 6.3 Richter Scale), accounting for 4,143 deaths, more 


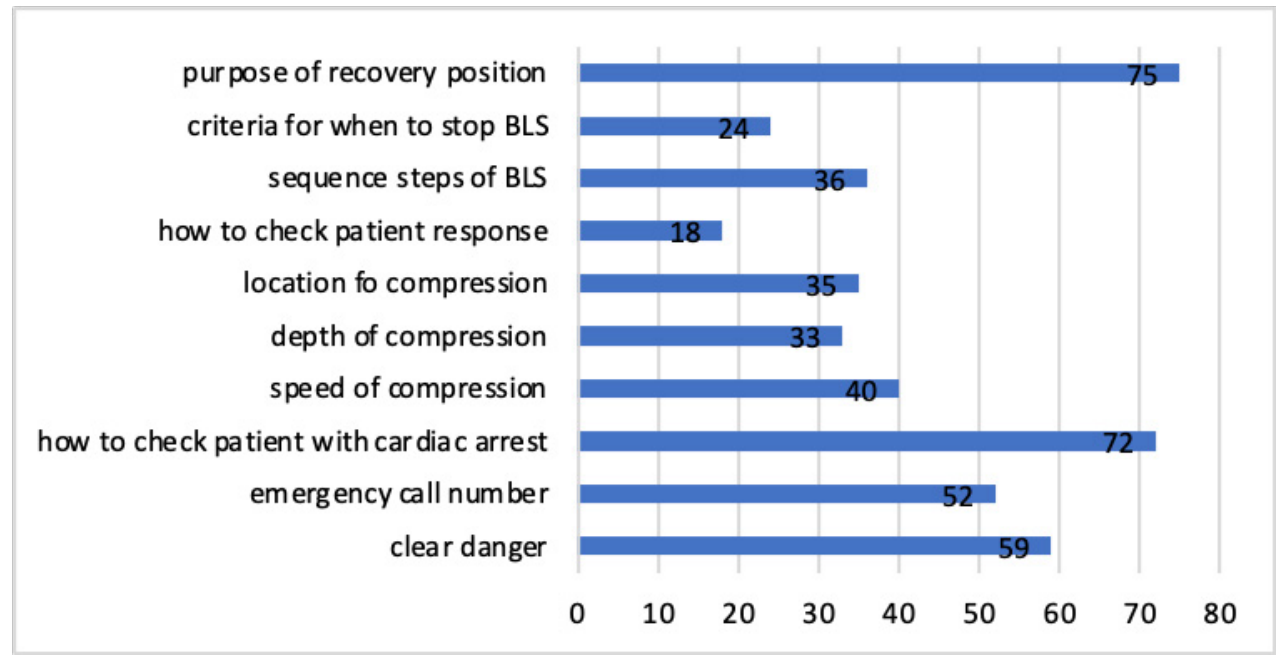

Figure 3. Frequency of correct answers on all items of BLS Knowledge.

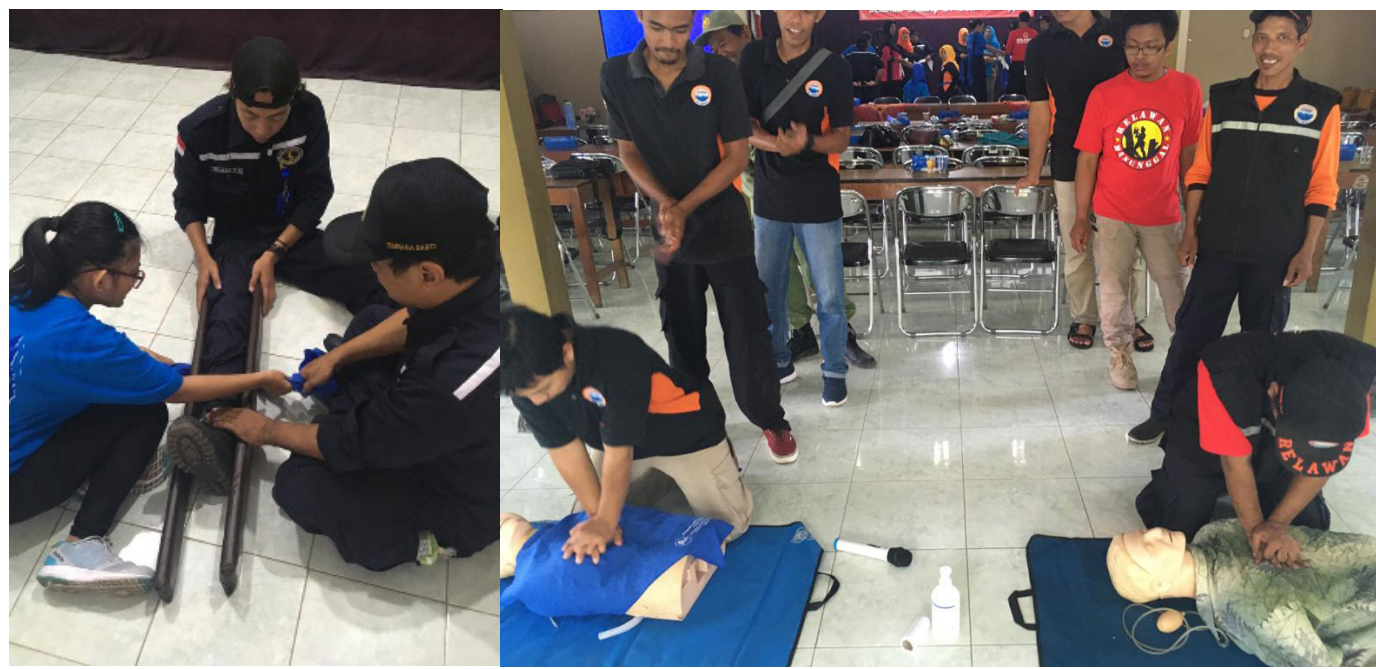

Figure 4. Basic Life Support and First Aid Training for FPRB in Bantul, March 2020.

than 12,000 were injured and nearly 80,000 houses were damaged (DIBI). An experience is an essential learning process that consists of a reflective process of past experiences and triggers the learning point. ${ }^{9}$ The disaster experiences also strengthen social trust and community involvement which are valuable to reduce disaster risk. ${ }^{10}$

Besides experiences, most participants had previous disaster training and education. A previous study revealed that disaster education can develop disaster preparedness in the community who have no previous disaster experience. ${ }^{11}$ Education can enhance the ability of abstract reasoning and anticipation skills. ${ }^{11}$ The FPRB members in Girirejo and Poncosari, Bantul had disaster simulation routinely organized by BPBD to optimize disaster preparedness. Related to location, this study was done in a tourist area (near Samas Beach) so that the people living there had open social culture. In line with a study in Pangandaran, Indonesia, an openminded society was able to accept new information as well as disaster information/education and have more ability to prepare for disaster. ${ }^{12}$

The results of this study revealed that participants have a high familiarity with disaster knowledge but less familiarity with early warning. This result is congruent with a study in China that found that more than half of the participants had advanced disaster response knowledge. ${ }^{8}$ People who live in high risk locations frequently experience natural hazards that 
trigger the community to promulgate information related to disaster preparedness and empower them to address the disaster risk. ${ }^{10}$ This reason reinforces the community to be concerned about the preventive measures and apply an action although they have no prior disaster experience. ${ }^{10}$

Most participants in this study have less familiarity with the early warning aspect. The rarity of earthquake incidence in Yogyakarta seems to influence the familiarity of early warning of FPRB members regarding information of early warning time and source of early warning information. An earthquake with high magnitude occurred over a decade ago so it can be assumed that respondents were less familiar with the early warning system. The learning process should be stimulated by an experience. ${ }^{9}$ Related to information of early warning and source of early warning information, most participants disagreed that they obtained information about aftershocks from television. Mobiles currently account for a greater amount of a person's time than television worldwide. Indonesian people spent more time using mobile (an average of 3 hours 26 minutes per day) on social media than watching television (an average of 3 hours 4 minutes per day). ${ }^{13}$ Social media is preferred because it transfers information quicker and is updated faster than mass media, although media sometimes report inaccurate information. To overcome inaccurate information about the disaster, the Indonesian government authorizes the Meteorological, Climatological and Geophysical Agency (BMKG) and The National Disaster Mitigation Agency (BNPB) as parts of the institutions designated as official sources of information to transmit disaster information to the public and to activate the early warning system. ${ }^{14}$

Development of emergency management programs are the responsibility of both professional and social groups, however, community volunteers as the front line in society also have a pivotal role to prevent exposure to local hazard. ${ }^{15,16}$ Results of this study showed that most participants have good knowledge of BLS. Congruent with the previous study, most of the University's health volunteers in Indonesia also have a good understanding of BLS. ${ }^{17}$ Community of Health Volunteers should have critical thinking in emergencies since the first 60 minutes is a golden time to rescue and save victims' life. ${ }^{18}$ Therefore, basic skills such as activating the early warning, BLS, first aid, and communication are essential for volunteers. ${ }^{19}$ Results of this study also found that most participants had poor knowledge of some BLS items. Thus, researchers and teams undertook BLS and first aid training for FPRB to improve their knowledge and skills after the data were collected (Figure 4).

\section{Conclusions}

This study found that most of the participants had a strong disaster preparedness. FPRB members have a good level of disaster knowledge aspect but have a fair level of early warning aspect. Even though the majority of FPRB have a good understanding of disaster preparedness and BLS, additional training and disaster simulation are necessary to be undertaken periodically.

\section{Limitations}

The results of this research have limited transferability and generalizability because it was conducted in only two locations. This study also used a questionnaire to evaluate disaster preparedness and BLS. The survey should be followed by observations to validate disaster preparedness levels. However, these results need to be considered because the evaluation of disaster preparedness and BLS level among FPRB members is rarely done.

\section{Acknowledgments}

The authors would like to acknowledge all of the FPRB members in Poncosari and Girirejo subdistricts, Bantul, and the funding support from the School of Nursing, Faculty of Medicine-Public Health and Nursing, Universitas Gadjah Mada.

\section{Conflict of interests}

No competing interests are declared.

\section{References}

1. Badan Nasional Penanggulangan Bencana. Rencana Nasional Penanggulangan Bencana 
2020 - 2024 [Internet] Jakarta: Badan Nasional Penanggulangan Bencana; 2020 [updated 2020; cited 2021]. Available from: https://www.bnpb. go.id/buku/rencana-nasional-penanggulanganbencana-20202024

2. Data Informasi Bencana Indonesia - Badan Nasional Penanggulangan Bencana; [Internet] Jakarta: Data Informasi Bencana Indonesia; 2019 [updated 2019; cited 2021]. Available from: http://dibi.bnpb.go.id/

3. United-Nations; Sendai Framework for Disaster Risk Reduction 2015 - 2030 [Internet]. New York and Geneva; 2015 [updated 2015; cited 2021]. Available from: https://www.preventionweb. net/files/43291_sendaiframeworkfordrren.pdf

4. Priester L De. An approach to the profile of disaster risk of Indonesia. Emerg Disaster Reports. 2016;3(2):66.

5. Badan Pusat Statistik Kabupaten Bantul; Luas Wilayah, Jumlah Penduduk, dan Rata-rata Jiwa per Km2 menurut Desa di Kabupaten Bantul; Yogyakarta: Badan Pusat Statistik Kabupaten Bantul; 2017 [updated 2017; cited 2021]. Available from: https://bantulkab.bps.go.id/ dynamictable/2018/10/30/36/luas-wilayahjumlah-penduduk-dan-rata-rata-jiwa-perkm-sup-2-sup-menurut-desa-di-kabupatenbantul-2017.html

6. LIPI-UNESCO. Kajian Kesiapsiagaan Masyarakat dalam Menghadapi Bencana Gempa Bumi dan Tsunami. Jakarta: Deputi ilmu pengentahuan kebumian LIPI; 2006.

7. Hatthakit U, Chaowalit A. Tsunami preparedness of people living in affected and non-affected areas: a comparative study in coastal area in Aceh, Indonesia. Australasian Emergency Nursing Journal. 2011 Feb 1;14(1):17-25.

8. Li T, Wang $Q, X i e Z$. Disaster response knowledge and its social determinants: A cross-sectional study in Beijing, China. PloS one. 2019 Mar 26;14(3):e0214367.

9. Kolb DA. Experiential learning: Experience as the source of learning and development. FT press; 2014 Dec 17.

10. Yamamura E. Learning effect and social capital: A case study of natural disaster from Japan. Regional Studies. 2010;44(8):1019-32.
11. Hoffmann R, Muttarak R. Learn from the past, prepare for the future: Impacts of education and experience on disaster preparedness in the Philippines and Thailand. World Development. 2017 Aug 1;96:32-51.

12. Marlyono SG, Nandi N. The preparedness level of community in facing disaster in West Java Province. InIOP Conference Series: Earth and Environmental Science 2018 Apr 1 (Vol. 145, No. 1, p. 012103). IOP Publishing.

13. We are social; Digital 2021: The latest insights into the "state of digital" [Internet] Newyork: we are social; 2021 [updated 2020; cited 2021]. Available from: https://wearesocial.com/ blog/2021/01/digital-2021-the-latest-insightsinto-the-state-of-digital

14. Badan Penanggulangan Bencana Nasional. Pedoman Sistem Peringatan Dini Berbasis Masyarakat [Internet]. Jakarta: 2012. Available from: https://bpbd.bantenprov.go.id/upload/ deni/foto/Pedoman_EWS_Masyarakat.pdf

15. Fulmer T, Portelli I, Foltin GL, Zimmerman R, Chachkes E, Goldfrank LR. Organization-based incident management: developing a disaster volunteer role on a university campus. Disaster Management \& Response. 2007 Jul 1;5(3):74-81.

16. Kamal A, Songwathana P, Sia WS. Knowledge and skills of emergency care during disaster for community health volunteers: a literature review. Nurse Media Journal of Nursing. 2012;2(2):37181.

17. Rahmi U, Sulastri A. Knowledge of the health volunteer team about basic life support (BLS) at Indonesia University of Education. STRADA Jurnal Ilmiah Kesehatan. 2020 Nov 1;9(2):353-7.

18. Thomas A. Humanitarian Logistics: Enabling Disaster Response, Fritz Institute, San Francisco. Retrieved on August, 20-10-2021 \#2 JCOEMPH edits with tracking_Happy_Is forum of disaster risk reduction ready Disaster preparedness in community setting 2003;19:2011.

19. Flint C, Brennan M. Community emergency response teams: From disaster responders to community builders. Rural Realities. 2006;1(3):19. 